\title{
Serological Studies on an $\alpha$-D-Galactosyl-Binding Lectin Isolated from Bandeiraea simplicifolia Seeds
}

\author{
W. J. Judd, E. A. Steiner, B. A. Friedman, C. E. Hayes and \\ I. J. Goldstein \\ Departments of Pathology and Biological Chemistry, University of Michigan, Ann Arbor, \\ Mich.
}

\begin{abstract}
The serological characteristics of a highly purified $a$-D-galactosyl-binding lectin, isolated from extracts of Bandeiraea simplicifolia seeds, are described. These studies show that the lectin preferentially agglutinates group $B$ red cells and in addition has the capacity to distinguish between group $A_{1}$ and group $A_{2}$ erythrocytes.

Since the lectin is not absolutely specific for group $B$ red cells, it is therefore unsuitable as an anti-B blood typing reagent. However, the reactions obtained against $\mathrm{Tn}$ and 'acquired-B' red cells suggest that it may be of value in the elucidation and classification of red cell polyagglutinable states.
\end{abstract}

\section{Introduction}

Anti-B hemagglutinating activity in extracts from Bandeiraea simplicifolia seeds was first reported by MÄKEL ̈̈̈ and MäKELÄ [5]. Recently, HAYES and GOLDSTEIN [3] purified an $a$-D-galactosyl-binding lectin from these seeds, and suggested that this reagent may be a suitable alternative to human group A serum as a source of anti-B for blood typing purposes.

This report details the serological behavior of the lectin, and describes a method for enhancing its in vitro activity. The reactions obtained against normal and anomalous ABO blood group phenotypes are presented, and the significance of these results is discussed.

Received: April 11, 1975; accepted: May 28, 1975. 


\section{Materials and Methods}

An $a$-D-galactosyl-binding lectin was isolated by affinity chromatography from extracts of Bandeiraea simplicifolia seeds as described previously [3].

Unless otherwise stated, serological studies were performed as follows: 2 vol of lectin ( $3 \mathrm{mg}$ of protein per $\mathrm{ml}$ in phosphate-buffered saline at $\mathrm{pH} 7.2$ ) were mixed with 1 vol of a $5 \%$ suspension of red cells (washed three times in isotonic saline at $\mathrm{pH} 7.2$ ) and immediately centrifuged at $3,400 \mathrm{rpm}$ for $15 \mathrm{sec}$. Tests were examined macroscopically for agglutination.

Details of other serological techniques have been described elsewhere [4].

Reactions were graded and scored according to the method of RACE and SANGER [7].

Initial studies with the lectin revealed that avid agglutination reactions against group $B$ red cells could only be achieved following the addition of human serum or bovine albumin to the reaction medium. These reactions were extremely difficult to read owing to the adhesion of agglutinates to the surface of glass test tubes. In view of this and the dependence of the lectin's agglutinating activity on the presence of calcium ions, the lectin was diluted in a solution containing 5 parts of a $22 \%$ bovine albumin, 4 parts of phosphate-buffered saline at $\mathrm{pH} 7.2$, and 1 part of a $0.1 \mathrm{~m}$ calcium chloride. To facilitate the reading of reactions, $0.02 \mathrm{ml}$ of Tween 20 was added to each $10 \mathrm{ml}$ of diluent.

\section{Results}

The reactions obtained with red cells from selected $A B O$ phenotypes at various dilutions of Bandeiraea simplicifolia lectin are shown in table I. These results clearly demonstrate the lectin's affinity for group B red cells, and its capacity to distinguish between group $A_{1}$ and group $A_{2}$ blood samples. A considerable variation in the reactivity of different samples of the same phenotype was found, as shown in table II. In addition, group B cord blood samples were shown to give weaker reactions than those obtained with group B red cells from adults.

Table III shows the results of tests using a 1:100 dilution of the lectin. All ten group $O$ samples tested were nonreactive, and one of 24 group A red cell samples was weakly agglutinated. Of 18 group B bloods studied, all were reactive; however, weak agglutination was observed with four samples. Increase in the incubation time to $5 \mathrm{~min}$ enhanced the reactions with group B red cells, but agglutination was also obtained with many of the group A red cell samples.

Absorption and elution studies showed that the activity of the lectin with group A red cells cannot be separated from that against group B cells.

Serological reactions were enhanced following the enzyme treatment of red cells as shown in table IV. Studies with enzyme-treated red cells from 
Table I. Reactions of selected ABO phenotypes with Bandeiraea simplicifolia lectin

\begin{tabular}{llllllllr}
\hline $\begin{array}{l}\text { ABO } \\
\text { phenotype }\end{array}$ & \multicolumn{6}{l}{ Reciprocals of lectin dilutions } \\
\cline { 2 - 8 } & 10 & 20 & 40 & 80 & 160 & 320 & 640 & Score \\
\hline $\mathrm{A}_{1}$ & $3+$ & $3+$ & $2+$ & $1+$ & 0 & 0 & 0 & 23 \\
$\mathrm{~A}_{2}$ & $1+$ & 0 & 0 & 0 & 0 & 0 & 0 & 5 \\
$\mathrm{~B}$ & $4+$ & $4+$ & $4+$ & $4+$ & $3+$ & $1+$ & 0 & 63 \\
$\mathrm{O}$ & 0 & 0 & 0 & 0 & 0 & 0 & 0 & 0 \\
\hline
\end{tabular}

Table II. Titration of B. simplicifolia lectin against randomly selected red cell samples from various $\mathrm{ABO}$ phenotypes

\begin{tabular}{|c|c|c|c|c|c|}
\hline \multirow{2}{*}{$\begin{array}{l}\mathrm{ABO} \\
\text { phenotype }\end{array}$} & \multirow{2}{*}{$\begin{array}{l}\text { Number } \\
\text { tested }\end{array}$} & \multicolumn{2}{|l|}{ Titer } & \multicolumn{2}{|l|}{ Score } \\
\hline & & mean & range & mean & range \\
\hline$A_{1}$ & 12 & 100 & $40-160$ & 30 & 2237 \\
\hline $\mathrm{A}_{2}$ & 3 & 20 & 0.40 & 14 & $0-20$ \\
\hline $\mathrm{B}$ & 16 & 580 & $320-640$ & 53 & $50-58$ \\
\hline$A_{1} B$ & 9 & 320 & 160640 & 46 & $41-56$ \\
\hline $\mathrm{A}_{2} \mathrm{~B}$ & 5 & 256 & $160-320$ & 50 & $48-51$ \\
\hline$B($ cord $)$ & 4 & 120 & 80160 & 29 & $21 \cdots 37$ \\
\hline
\end{tabular}

Table III. Reactions of different examples of groups A, B and O red cell samples with a $1: 100$ dilution of lectin

\begin{tabular}{|c|c|c|c|c|c|c|}
\hline \multirow{2}{*}{$\begin{array}{l}\text { ABO } \\
\text { phenotype }\end{array}$} & \multirow{2}{*}{$\begin{array}{l}\text { Total number } \\
\text { tested }\end{array}$} & \multicolumn{5}{|c|}{ Number of samples giving reactions of } \\
\hline & & $4+$ & $3+$ & $2+$ & $1+$ & 0 \\
\hline $\mathrm{O}$ & 10 & & & & & $10(10)$ \\
\hline A & 24 & (1) & $(2)$ & $(2)$ & $1(5)$ & $23(14)$ \\
\hline B & 18 & $5(18)$ & 9 & 4 & & \\
\hline
\end{tabular}

Figures in parentheses represent reactions after 5 min incubation. 
Table $I V$. The effect of enzyme (ficin) treatment of red cells in enhancing the agglutinating activity of the lectin

\begin{tabular}{|c|c|c|c|c|}
\hline \multirow[t]{2}{*}{ ABO type } & \multicolumn{2}{|c|}{ Untreated red cells } & \multicolumn{2}{|c|}{ Ficin-treated cells } \\
\hline & titer & score & titer & score \\
\hline $\mathrm{O}$ & 0 & 0 & 80 & 18 \\
\hline$A_{1}$ & 80 & 26 & 5,000 & 99 \\
\hline $\mathrm{A}_{2}$ & 20 & 13 & 320 & 48 \\
\hline $\mathrm{B}$ & 640 & 53 & 20,000 & 117 \\
\hline
\end{tabular}

Table $V$. Reactions obtained with red cells from unusual blood group phenotypes following treatment with ficin

\begin{tabular}{|c|c|c|c|c|}
\hline \multirow[t]{2}{*}{ Red cell phenotype } & \multicolumn{2}{|c|}{ Untreated red cells } & \multicolumn{2}{|c|}{ Ficin-treated red cells } \\
\hline & titer & score & titer & score \\
\hline Oh (Bombay) & $\mathbf{0}$ & & 40 & 23 \\
\hline $\mathrm{B}^{h} \mathrm{~m}$ & 0 & & 80 & 26 \\
\hline $\mathrm{O}, \mathrm{Sd}(\mathrm{a}+)$ & 0 & & 40 & 25 \\
\hline \multicolumn{5}{|l|}{$O, \operatorname{Sd}(\mathrm{a}++)$, strong } \\
\hline reactor & 0 & & 80 & 33 \\
\hline$O, \operatorname{Sd}(\mathrm{a}-)$ & 0 & & 40 & 25 \\
\hline$O, p\left(\mathrm{Tj}^{a}-\right)$ & 0 & & 40 & 23 \\
\hline $\mathrm{O}, \mathrm{P}_{1}$ & 0 & & 80 & 26 \\
\hline $\mathrm{O}, \mathrm{P}_{2}$ & 0 & & 80 & 33 \\
\hline \multicolumn{5}{|l|}{ O, Tn-poly- } \\
\hline agglutinable & 2,560 & 81 & 80 & 33 \\
\hline $\mathrm{O}, \mathrm{T}$-activated & 40 & 23 & & \\
\hline$A_{1}(B)$ ('acquired B') & 80 & 35 & & \\
\hline
\end{tabular}

Table VI. Reactions of 'acquired-B' $\left[\mathrm{A}_{1}(\mathrm{~B})\right]$ red cells with $B$. simplicifolia lectin and human anti-B reagents

\begin{tabular}{llrl}
\hline Reagent & Cell type & Titer & Score \\
\hline B. simplicifolia lectin & $\mathrm{A}_{1}(\mathrm{~B})$ & 80 & 27 \\
& normal group B & 320 & 63 \\
Human anti-B & $\mathrm{A}_{1}(\mathrm{~B})$ & 640 & 69 \\
& normal group B & 640 & 71 \\
\hline
\end{tabular}


individuals of unusual $\mathrm{ABO}$ phenotype, selected phenotypes within the $\mathrm{P}$ and $\mathrm{Sd}^{\mathrm{a}}$ blood group systems, and cases of red cell polyagglutination are presented in table V. In marked contrast to the reactions of untreated cells, the lectin was found to react with enzyme-treated group $\mathrm{O}$ red cells. The strong reactions observed with group $O$ Tn-polyagglutinable red cells were decreased following treatment of the cells with ficin. The lectin weakly agglutinated group $A_{1}(B)$ ('acquired B') red cells. When tested with anti-B from group $A$ individuals, these cells were found to react comparably to normal group B red cells as shown in table VI.

The hemagglutinating activity of the lectin against either group $A_{1}$, group $\mathrm{B}$, ficin-treated group $\mathrm{O}$ or group $\mathrm{O} T \mathrm{n}$ red cells was readily abolished by saliva samples from secretors of $B$ substance, and to a lesser degree by hydatid cyst fluids and group A secretor saliva samples. Group O secretor and nonsecretor salivas, and one group $B$ nonsecretor saliva sample, were noninhibitory.

\section{Discussion}

A number of lectins and protectins with blood group A specificity have been described, and the use of these reagents is well established. The search for a suitable alternative to human group A serum as a source of anti-B has, however, yet to be fulfilled. A method for the large scale production of anti-B from the fungus Fomes fomentarius has been described by PARDOE et al. [6], but this reagent is somewhat unstable. The findings by MäKEL $\ddot{A}$ and MÄKELÄ [5] of anti-B activity in saline extracts of Bandeiraea simplicifolia seeds led to the isolation and purification from these seeds of an $a$-Dgalactosyl-binding lectin by HAYES and GOLDSTEIN [3]. These workers suggested that this lectin may prove suitable as an alternative to human sources for an anti-B blood typing reagent.

The results of the studies presented in this publication demonstrate that the $\alpha$-D-galactosyl-binding lectin from the seeds of Bandeiraea simplicifolia has limitations with regard to its routine use as an anti- $B$ typing reagent. The results of titration experiments show such a wide variation in the reactivity of different examples of the same $A B O$ type that at no one dilution will reactions specific for group $B$ cells be obtained, although at a 1:100 dilution level the lectin preferentially agglutinated group B red cells. Furthermore, the activity for group A cells cannot be separated by absorption and elution techniques from the activity against group $B$ red cells. This latter 
finding confirms the biochemical analysis of the lectin [3] which indicates that the purified protein is homogeneous.

The inhibitory effect of hydatid cyst fluids on the lectin's hemagglutinating activity is not surprising in view of the studies of WATKINS and MORGAN [8], which show that $\alpha$-D-galactosyl residues are the immunodominant sugars involved with $\mathrm{P}$ blood group specificity. However, we were unable to demonstrate any such specificity by hemagglutination tests using untreated and protease-treated $P_{1}, P_{2}$ and $p$ red cells. Presumably this is because the $P$ blood group determinants on erythrocyte membranes are not readily accessible to the lectin's antigen-combining sites.

The strong reactivity of Tn-polyagglutinable red cells with the lectin is most likely due to the cryptic A-like receptors on these red cells, as shown by DAHR et al. [2], and the weak binding of $N$-acetyl-D-galactosamine to the lectin in addition to its affinity for D-galactose [3]. Since we were unable to demonstrate any increase in agglutination reactions with group $\mathrm{O}$ $\mathrm{Sd}^{\mathrm{a}}++(\mathrm{Cad} 2) \mathrm{red}$ cells, it is suggested that Bandeiraea simplicifolia lectin may provide a more readily available source of reagent than the Salvia lectins described by BIRD and WINGHAM [1] for the elucidation and classification of red cell polyagglutinable states. Some initial studies performed on crude saline extracts of Bandeiraea simplicifolia seeds suggest that they may be used for this purpose. Similarly, the results obtained when 'acquired B' red cells are tested with the purified lectin, in contrast to when human anti-B reagents are used, indicate the potential value of the lectin in the serological diagnosis of the acquired-B phenomenon.

\section{Acknowledgment}

These studies were supported in part by NIH grant AM 10171.

We wish to thank Mr. W. L. Marsh and Mr. J. Moulds for providing some of the unusual red cell types used in this investigation.

\section{References}

1 Bird, G. W. G. and Wingham, J.: Haemagglutinins from Salvia. Vox Sang. 26: 163 (1974).

2 Dahr, W.; Uhlenbruck, G., and Bird, G. W. G.: Cryptic A-like receptor sites in human erythrocyte glycoproteins: proposed nature of Tn antigen. Vox Sang. 27: 29 (1974). 
3 HAYes, C. E. and Goldstein, I. J.: An a-D-galactosyl binding lectin from Bandeiraea simplicifolia seeds. J. biol. Chem. 249: 1904 (1974).

4 JUDD, W. J.: A bromelin dependent panagglutinin. Vox Sang. 25: 166 (1973).

5 MÄKELÄ, O. and MÄKELÄ, P.: Some new blood group specific phytagglutinins. Annls Med. exp. Biol. Fenn. 34: 402 (1956).

6 Pardoe, G. I.; Uhlenbruck, G.; Anstee, D. J., and Reifenberg, U.: On the specificity of broad spectrum agglutinins. III. Heterophile agglutinins associated with anti-B-like specificity. Z. ImmunForsch. exp. Ther. 139: 468- 485 (1970).

7 Race, R. R. and SANGer, R.: Blood groups in man (Blackwell, Oxford 1958).

8 Watkins, W. M. and Morgan, W. T. J. : Blood-group $P_{1}$ substance. II. Immunological properties. Proc. 9th Congr. Int. Soc. Blood Transfusion, Mexico, p. 230 (1962).

Mr. W. J. JuDD, FIMLT, Department of Pathology, University of Michigan, 1335 E. Catherine Street, Ann Arbor, MI 48104 (USA) 